\title{
THE MYENTERIC PLEXUS IN INFANTILE HYPERTROPHIC PYLORIC STENOSIS
}

\author{
BY \\ J. R. RINTOUL and N. F. KIRKMAN \\ From the Department of Anatomy, University of St. Andrews, and Department of Anatomy, \\ University of Manchester and Duchess of York Hospital for Babies, Manchester
}

(RECEIVED FOR PUBLICATION MARCH 29, 1961)

The aetiology of pyloric stenosis in infants is still uncertain. Since the early description of the condition by Blair (1717) various theories of pathogenesis have been formulated. It is now generally accepted that there is a defect in a gene. Carter and Powell (1954), by tracing the offspring of parents, one of whom had pyloric stenosis, showed that one son out of 10 and one daughter out of 50 born to such parents, would develop pyloric stenosis. This view is supported by the fact that the present incidence of three to four cases per 1,000 live births is much higher than the incidence recognized before 1900 (Cautley and Dent, 1903), which in turn may be attributable to the high survival rate of infants operated on for this condition (Wood and Smellie, 1951; Gross, 1953; Aird, 1957; Svenson, 1958).

Recent investigators have suggested that the condition may be the sequela to autonomic imbalance in the stomach (Cameron, 1925; Bendix and Necheles, 1947). Various aetiological theories have been advanced to explain this hypothesis. Some workers (Friesen, Boley and Miller, 1956; Taylor, 1959) believed that immaturity of the myenteric ganglion cells was the primary factor, while others (Herbst, 1934; Belding and Kernohan, 1953; Alarotu, 1956; Nielsen, 1956; Roberts, 1959) considered that degeneration of these neurons was responsible for the disease.

According to Friesen et al. (1956) the pyloric myenteric ganglia in cases of hypertrophic stenosis contain many undifferentiated cells. The presence of these cells suggested that final maturation of the ganglion cells, which normally occurs two to four weeks after birth, had been arrested or delayed. Roberts (1959), on the other hand, postulated that if this explanation were true, then one might expect an increased incidence of hypertrophic stenosis in premature infants.

Those claiming to have obtained microscopical evidence of degenerative changes in the myenteric ganglion cells differ somewhat in their descriptions of the signs of degeneration observed. Belding and Kernohan (1953) examined the stomachs of nine infants who had died from congenital pyloric stenosis and found that the majority of ganglion cells had undergone changes. The nuclear membrane was indistinct and the nucleolus appeared to be separated into two or three segments or to have disintegrated entirely. Numerous 'ghost cells' were found in all sections of the pylorus. These cells appeared merely as faint outlines of normal ganglion cells which had lost their normal staining reactions. Alarotu (1956) observed degenerative changes of varying severity in the pyloric myenteric ganglion cells. These changes appeared to occur with a certain regularity which enabled him to classify them into four types. Marked activity in the degenerating cells was manifested by increase in the size of the nucleolus and intense staining of the nuclear membrane. The nucleus was eccentric in position and frequently possessed two or more nucleoli. Severe degeneration was characterized by disintegration of the nucleus and ultimately by disappearance of the ganglion cells. Nielsen (1956) made similar observations from biopsy specimens obtained from the pyloric musculature of 15 infants submitted for surgical treatment of congenital pyloric stenosis. He reported severe degenerative changes in the intramuscular ganglion cells, the degree and type of degeneration varying from one specimen to another. In some specimens the cells showed evidence of chromatolysis; in others many atrophic cells were found. 'In the atrophic form the cells were excessively shrunken with a highly pyknotic nucleus.'

In addition to those changes in the ganglion cells a marked increase in the number of satellite cell nuclei and a pronounced proliferation of intercellular connective tissue was observed by those authors (Belding and Kernohan, 1953; Alarotu, 1956; Nielsen, 1956). Roberts (1959), however, 
while he agreed with those workers that the ganglia were fewer in number and smaller in size in the abnormal pylorus, maintained that the cells were more tightly packed together than those in normal pyloruses.

Because of these differences of opinion we have reinvestigated the problem from the viewpoint of possible abnormality in the intrinsic innervation of the pylorus by examining the myenteric plexus in biopsy specimens of pyloric musculature from 38 infants with hypertrophic stenosis. The morphological appearance of the ganglion cells in those specimens was compared with that of the myenteric ganglion cells in normal pyloruses.

\section{Material}

Patients with congenital pyloric stenosis were treated by a wedge resection of pyloric muscle instead of a single pylorotomy as in Ramstedt's operation. Fig. 1 illustrates how the wedge biopsy was taken. The average size of the biopsy specimens was $10 \times 4 \times 3 \mathrm{~mm}$.

Control material consisted of: (a) normal stomachs obtained from nine infants who had died from unrelated causes shortly after birth; (b) fresh tissue specimens of adult pylorus (six), duodenum (two), descending colon (two), secured at operation from patients who were treated surgically for gastric ulceration or carcinoma of the rectum.

\section{Histological Methods}

The biopsy and control material were placed in $20 \%$ (Analar) formalin immediately after excision.

Of the various neurohistological and routine staining methods used, the following gave the most satisfactory results: (A) A modified Bielschowsky-Gros silver impregnation technique; (B) haematoxylin (Delafield's) and eosin staining. Frozen sections $40 \mu$ thick were used in method (A) and serial paraffin sections in method (B). Before staining, the material to be submitted to haematoxylin and eosin staining, was either embedded in paraffin wax in the usual manner or prepared by the 'double embedding technique'. In the latter method the material, after dehydration, wasi immersed in $10 \%$ low viscosity nitrocellulose dissolved in methyl salicylate. When the material became transparent (usually after 24 to 48 hours) it was placed in. benzene (two changes) to 'clear', transferred to paraffin baths and finally embedded in paraffin wax.

\section{Observations}

The examination of the biopsy and the control material was mainly concerned with a study of the morphological appearance of the myenteric ganglion cells and the structure of the nerve fibre tracts. Estimations of the total number of ganglia or of the number of ganglion cells present per unit area of muscle tissue were not undertaken since accurate measurements of the irregular wedge-shaped biopsy

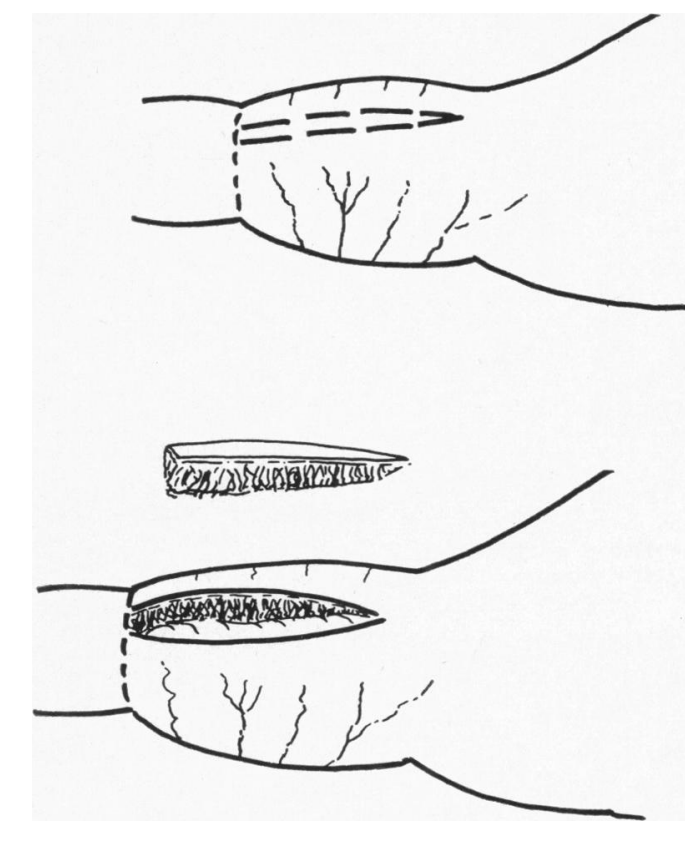

Fig. 1.-Diagram showing how the segment of pyloric musculature was obtained for examination.

specimens were not possible. It is, however, well recognized that successful staining of all neural elements throughout an entire section is seldom, if ever, achieved where neurohistological staining methods are used.

In silver-stained preparations of the fresh control material (pylorus, duodenum, descending colon) two distinct ganglion cell types were recognized (Figs. 2, 3, 4, 5). One variety corresponded to the Type I cells described by Dogiel (1899). This cell type showed a marked affinity for silver, exhibiting heavy staining of the cell cytoplasm and cell processes and pale staining of the nucleus. The second cell type (Dogiel Type II) was found to be less argentophilic than Type I (Dogiel) cells and showed pale staining of the cytoplasm and heavier impregnation of the nucleus. The cell processes of the Type II cells usually remain unstained (Rintoul, 1959, 1960).

It has been observed previously (Rintoul, 1959) that the distribution of these different neuronal types appears to vary in different regions of the alimentary tract. This has been corroborated in the present study. Type II (Dogiel) cells were found to be uniformly distributed throughout the myenteric ganglia in both the control and biopsy material, whereas the more markedly argentophilic Type I cell appeared to be absent from tissue sections 


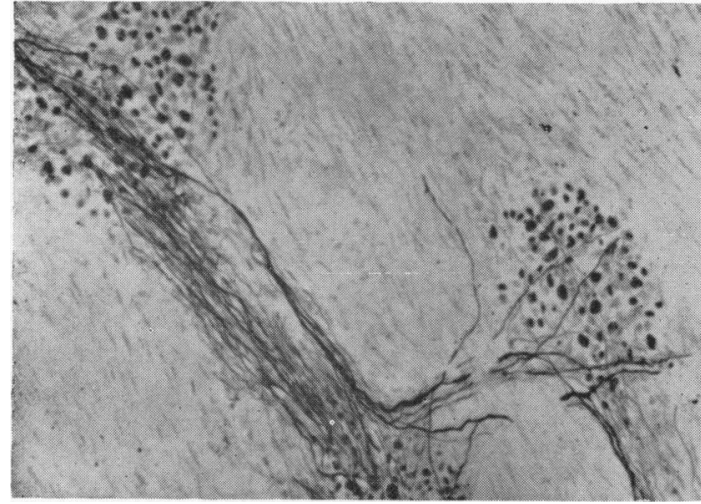

Fig. 2.-Portion of myenteric plexus from an autopsy specimen of normal infant pylorus. The cytoplasm of the ganglion cells (Type II) is faintly stained although the nuclei are heavily impregnated. (Modified Bielschowsky-Gros preparation. $\times 75$.)

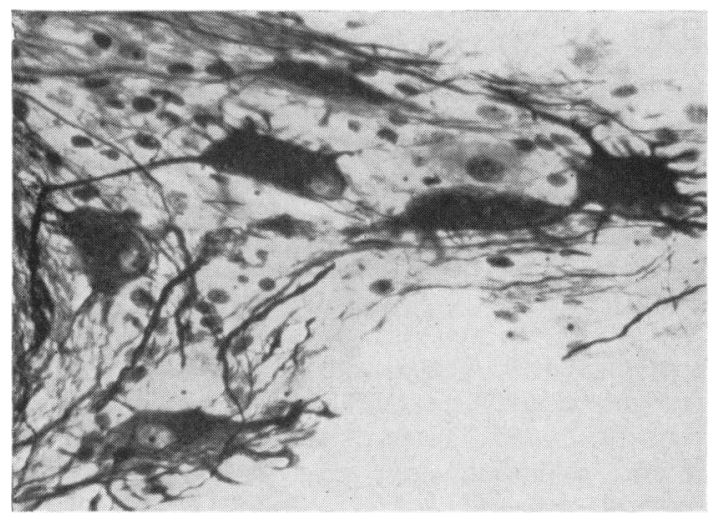

Fig. 4.-Myenteric ganglion in adult duodenum, showing Types I and II (Dogiel) neurons (control specimen). (Modified BielschowskyGros preparation. $\times 250$.

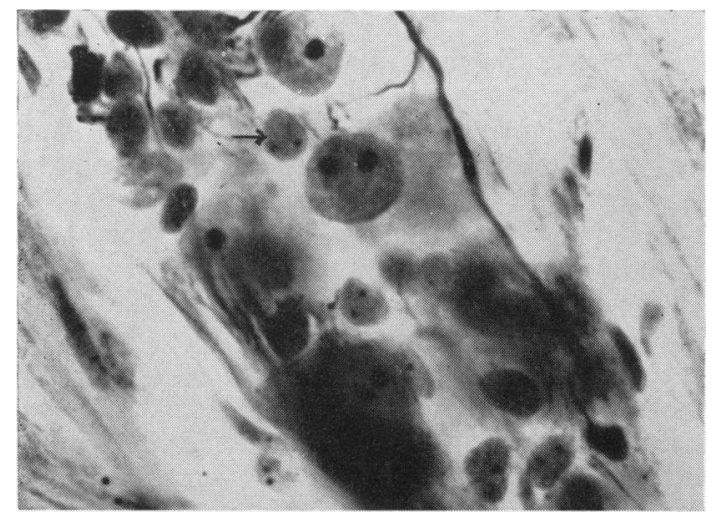

Fig. 6.-Myenteric ganglion in a biopsy specimen from an infant suffering from congenital pyloric stenosis. The ganglion cells which are of the Type II (Dogiel) variety show no obvious signs of degenerative change. Several satellite cell nuclei are visible, one of which is indicated by an arrow. (Modified Bielschowsky-Gros preparation. $\times 400$.)

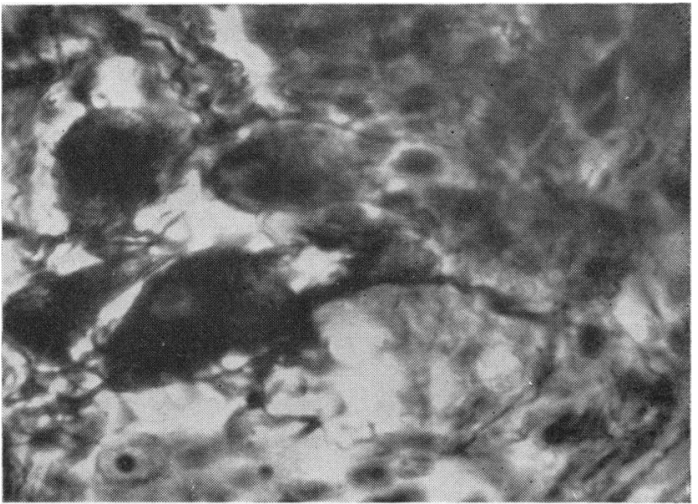

Fig. 3.-Myenteric ganglion in fiesh control specimen of adult pylorus, showing Type I (Dogiel) neurons. (Modified Bielschowsky Gros preparation. $\times 400$.

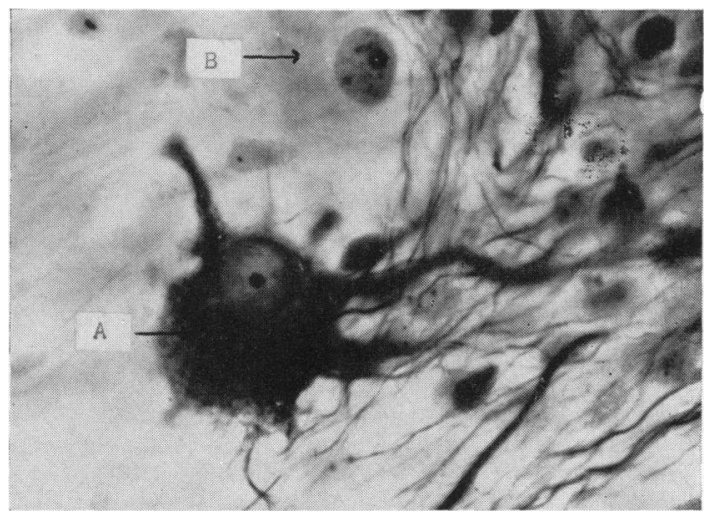

FIG. 5.-Normal myenteric ganglion from descending colon of an adult. Pointer (A) indicates a typical Type I (Dogiel) cell; pointer (B) indicates a Type II (Dogiel) cell. (Modified Bielschowsky-Gros preparation. $\times 400$.

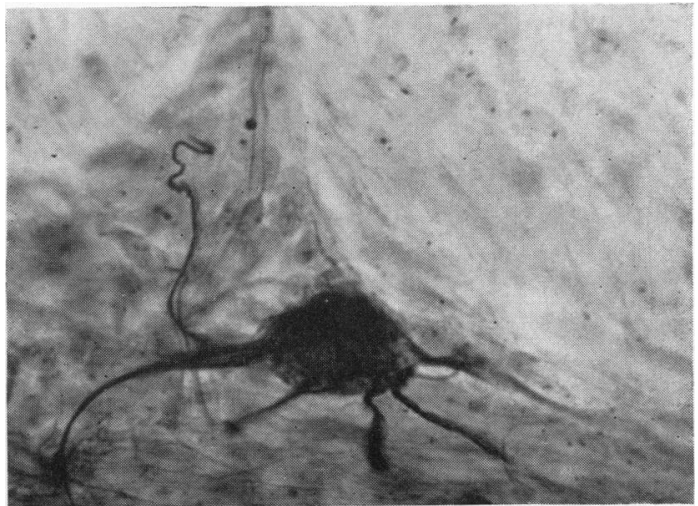

Fig. 7.-Pyloric myenteric ganglion from a biopsy srecimen obtained at operation from an infant suffering from congenital pyloric stenosis. The argentophil Type I (Dogiel) cell shown is rarely found in such specimens. (Modified Bielschowsky-Gros preparation. $\times 400$.) 
of the biopsy material obtained from infants suffering from congenital pyloric stenosis.

There is, however, an exception to this observation. One section from several hundred silverstained sections of biopsy specimens of pylorus (from infants suffering from hypertrophic stenosis) showed two type I neurons, one of which is illustrated in Fig. 7. In neither of these cells was the nucleus visible. The absence, or virtual absence, of Type I cells from the pyloric myenteric ganglia in the biopsy material suggests either that these cells were congenitally absent or that they had degenerated.

Careful scrutiny of the neurons (Type II) forming the pyloric myenteric ganglia in the biopsy specimens in silver-stained preparations failed to reveal the degenerative changes described by Belding and Kernohan (1953) and Nielsen (1956). Disappearance or fragmentation of the nucleoli or nuclear membranes, or pyknosis of the ganglion cells or their nuclei, such as those authors described, were not observed. Alarotu (1956) states that the presence of two or more nucleoli within the nuclei of the ganglion cells is indicative of increased physiological activity and that sustained stimulation of these ganglion cells ultimately leads to their degeneration. It is true that ganglion cells exhibiting two nucleoli may be seen in sections of biopsy specimens of the pyloric musculature (Fig. 6), but the more advanced signs of degeneration such as disintegration of the nuclei were not evident. Satisfactory staining of Type II neurons was not obtained in all the biopsy specimens and this, together with the absence of Type I cells might be interpreted as indicating that degeneration of ganglion cells had occurred. Nevertheless, comparison with the control material revealed no obvious reduction in the numbers of the neurons nor an increased glial proliferation within the ganglia in the biopsy specimens of pylorus from cases of congenital pyloric stenosis. Furthermore, the nerve fibres within the tracts of the plexus were also normal in appearance.

Those investigators who claimed to have observed degenerative changes in the pyloric myenteric ganglion cells in individuals suffering from hypertrophic stenosis employed routine histological staining methods, including cresyl violet, gallocyanine and haematoxylin and eosin. Using those methods microscopical appearances suggestive of degenerative change were frequently observed in both the biopsy and the control material. This appeared to be associated with the method of preparation of the specimen and was most evident in specimens prepared for sectioning by the usual procedure of embedding in paraffin wax. In those cases the ganglion cells were often shrunken and showed indistinct cells and nuclear membranes and pale staining of the cytoplasm. At times shadows of cells only were visible. These results are consistent with Nielsen's (1956) descriptions of ganglion cells undergoing chromatolytic degeneration. If, however, the double embedding technique (see 'Histological Methods') was used before the material was sectioned a different picture was obtained. The myenteric ganglion cells then have a more uniform appearance, showing distinct nuclear membranes and prominent nucleoli. Fig. 9 shows the typical appearance of the ganglion cells from a biopsy specimen prepared by the double embedding method and stained by haematoxylin and eosin. Evidence of autolytic change was observed only in some of the control material which had been obtained at autopsy and fixed several hours after death (Fig. 10). The microscopic picture of the myenteric ganglia in fresh control material (Figs. 8 and 11) was essentially similar in appearance to that seen in the biopsy material from cases of congenital pyloric stenosis (Fig. 9). Adequate staining of the ganglion cells was not, however, obtained in all of the specimens of the biopsy and control material examined. This defect in staining appeared to be more evident in preparations of infantile pylorus, derived from both the biopsy and control specimens, than in preparations of fresh control adult material. In the latter the ganglion cells were more clearly revealed by the stain (Figs. 8 and 11).

\section{Discussion and Conclusions}

Various theories have been advanced regarding the aetiology and pathogenesis of infantile hypertrophic pyloric stenosis. Current opinion suggests that the condition develops as a result of a defect in the intrinsic nerve supply to the pylorus. There are two opposing views: (i) that the ganglion cells are immature due to delayed or arrested development; and (ii) that the ganglion cells undergo degeneration as a result of abnormal parasympathetic (vagal) stimulation.

Friesen et al. (1956), who held the former view, examined the myenteric plexus in biopsy specimens of pylorus from 18 patients suffering from the disease. They found that the number of mature ganglion cells appeared to be considerably fewer in the biopsy material than in similar specimens of normal pyloruses, although the total number of ganglion cells per unit area was essentially the same in both. Those authors did not indicate, however, what 


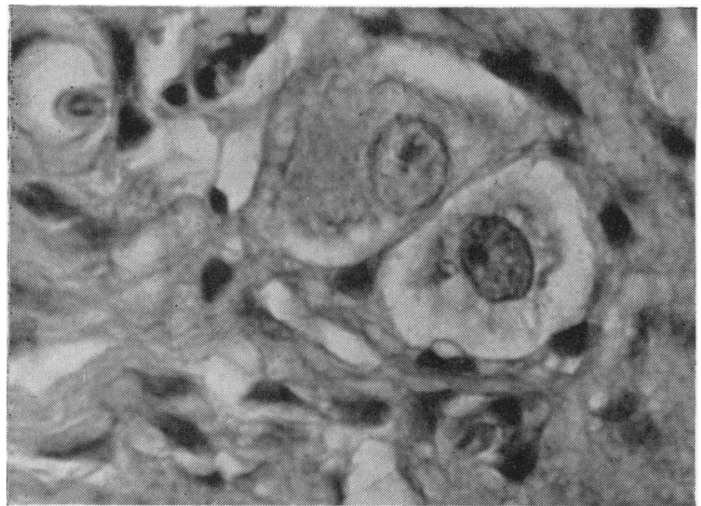

FIG. 8.-Pyloric myenteric ganglion from a biopsy specimen of normal adult pylorus. The considerable shrinkage of the cells which is usual in paraffin embedded specimens is evident. (Haematoxylin and eosin $\times 400$.)

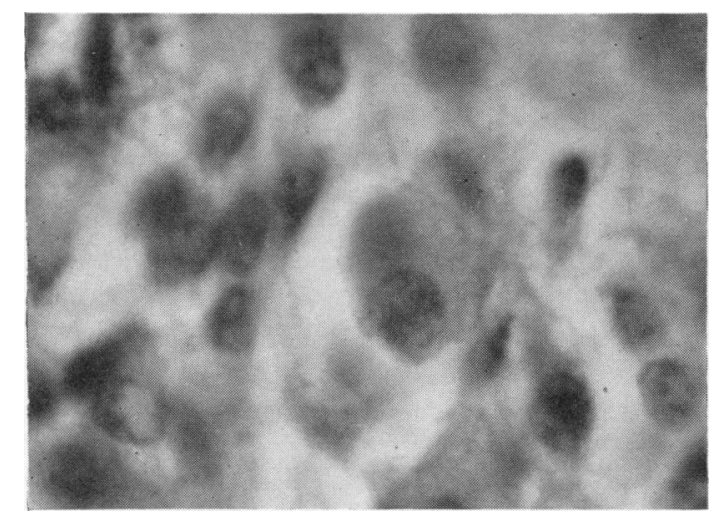

Fig. 10.-Myenteric ganglion from an infant pylorus obtained at autopsy (control specimen). Ganglion cells show evidence of autolytic change. (Haematoxylin and eosin $\times$ 400.)

criteria they used to distinguish mature from immature neurons.

Other investigators (Belding and Kernohan, 1953; Alarotu, 1956; Nielsen, 1956) have disputed these findings. They believed that the total number of ganglion cells per unit area was considerably less than normal in the pyloric myenteric plexus of patients with congenital pyloric stenosis, and that this reduction was due to the disappearance of neurons which had undergone degeneration. Abnormal neurogenic impulses mediated by preganglionic vagal fibres were thought to be responsible for such degeneration. Belding and Kernohan (1953) and Alarotu (1956), considered that the microscopical appearance of these degenerating ganglion cells was identical to the histological picture obtained experimentally after prolonged

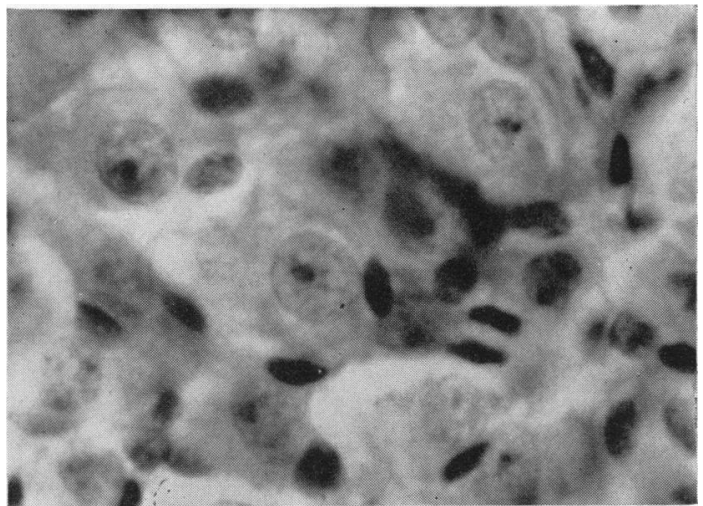

Fig. 9.-Myenteric ganglion of pylorus of an infant operated on for congenital pyloric stenosis. The ganglion cells appear normal and show well-defined nuclear membranes and nucleoli. Specimen prepared by 'double embedding' technique. $(\times 400$. $)$

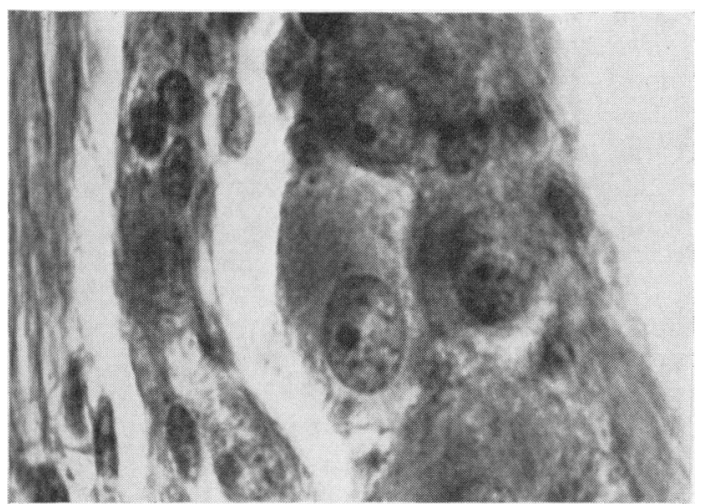

FIG. 11.-Myenteric ganglion from descending colon of an adult (control specimen). Ganglion cells appear normal and show no evidence of shrinkage. Prepared by 'double embedding' technique. (Haematoxylin and eosin $\times 400$.)

stimulation of the vagus nerves. Moreover, in those cases where degeneration of the neurons had reached an advanced stage an increased proliferation of the intraganglionic glial tissue was usually evident (Nielsen, 1956).

In this investigation 38 biopsy specimens of pyloric muscle, obtained at operation from children with congenital hypertrophic stenosis, were examined histologically for evidence of immaturity or degeneration of the myenteric ganglion cells. The view that the ganglion cells were immature was tested by comparing the microscopical appearance of the cells present in the biopsy specimens with those of the control series which had been prepared for histological examination in an identical manner. The control specimens included material from the digestive tract of both infants and adults. Where 
routine staining methods such as haematoxylin and eosin were used, it was observed that the ganglion cells were more difficult to stain in preparations of infant pylorus (from both biopsy and control material) than those in preparations of fresh adult control specimens. Since no such difference was noted in silver-stained preparations, we are unable to comment further on this observation.

Staining of the myenteric plexus by a silver impregnation technique was found to give more consistent results than those obtained by using routine laboratory staining methods. In sections prepared by the former method the myenteric ganglia were found to comprise several layers of closely packed cells with the minimum of supporting tissue. Two morphologically distinct ganglion cell types were recognized in tissue sections of the fresh control material. These cells types appeared to correspond to the Types I and II neurons described by Dogiel (1899). The Type I (Dogiel) cell was observed to be more markedly argyrophilic than the Type II (Dogiel) neuron. Examination of silver-stained preparations of the biopsy material showed that the argyrophilic Type I (Dogiel) cell was virtually absent from the pyloric myenteric ganglia in specimens from infants suffering from congenital pyloric stenosis, although no obvious reduction in the numbers of Type II (Dogiel) cells was noted. Whether the absence of the Type I cells is due to degeneration of these cells subsequent to excessive parasympathetic stimulation, or is attributable to some failure in their development is uncertain. It is noteworthy, however, that no evidence of disintegration and ultimate disappearance of neurons accompanied by replacement overgrowth of connective tissue was observed in those sections where adequate staining of the neurons was achieved.

Since previous workers have found that routine staining methods (including cresyl violet, gallocyanine and haematoxylin and eosin) were more satisfactory than neurohistological methods for revealing evidence of neuronal degeneration, preparations stained by these methods were also tried. It was found that where the specimens were prepared for histological examination by the usual method of paraffin wax embedding considerable shrinkage of the tissue occurred and indifferent staining of the pyloric myenteric ganglion cells frequently resulted. Shrinkage of the cell bodies and nuclei, together with pale staining of the cell cytoplasm and ill-defined cell boundaries gave a histological picture indistinguishable from that described by Nielsen (1956) as indicating early degenerative change in the myenteric ganglion cells.
Since, however, similar appearances were obtained in the control specimens (Fig. 8), such evidence alone must be regarded as inconclusive and probably the result of inadequacies in the staining procedures employed.

Routine staining methods were found, however, to give results comparable to those obtained by the silver impregnation method when the tissue was first prepared for histological examination by the 'double embedding' technique. This method resulted in less shrinkage and distortion of tissue than simple paraffin wax embedding. Subsequent staining with haematoxylin and eosin was found to be more complete and uniform when the 'double embedding' method was used. Nevertheless, despite the improvements in staining obtained by this method, conclusive evidence either against the degeneration theory or in support of it was not secured because the ganglion cells were always more completely stained in specimens of adult than in specimens of infant pylorus. Certainly it is true that no advanced signs of neuronal degeneration, such as previous workers' have described, were found. The possibility that early degenerative changes in the neurons are present, but have not been revealed by the staining procedures used, cannot be excluded.

\section{Summary}

Current opinion suggests that the primary factor in the aetiology of infantile hypertrophic stenosis is a defect in the pyloric myenteric plexus. One view holds that the ganglion cells are immature; another that the cells are degenerated.

Thirty-eight biopsy specimens of pyloric musculature from infants treated surgically for the condition were examined histologically and compared with similar sections from control material. It was found that there were present in normal pylorus two morphologically distinct ganglion cell types corresponding to (Dogiel) Types I and II neurons, but that (Dogiel) Type I neurons were virtually absent from the pylorus in congenital pyloric stenosis. Whether the absence of Type I cells is due to degeneration of these cells subsequent to excessive parasympathetic stimulation or to some failure in their development is uncertain.

No evidence of advanced neuronal degeneration in biopsy specimens of pylorus from infants suffering from congenital pyloric stenosis was found. Signs of nerve degeneration described by previous workers may be artefacts caused by imperfect methods of preparation of tissue for histological examination.

We wish to thank Professor G. A. G. Mitchell of the Anatomy Department of Manchester University for 
his encouragement and advice during the period of this research and for the facilities which he provided in his Department.

Our thanks are also due to Dr. L. Stent of the Pathology Department of Withington Hospital, Manchester, for the provision of the autopsy specimens.

We also wish to acknowledge with gratitude the assistance given by Mr. L. Cooke in the preparation of the histological sections and that given by Mr. P. Howarth and Mr. J. Brown for the preparation of the photomicrographs.

\section{REFERENCES}

Aird, I. (1957). A Companion in Surgical Studies, p. 1060. Livingstone, Edinburgh.

Alarotu, H. (1956). The histopathologic changes in the myenteric plexus of the pylorus in hypertrophic pyloric stenosis in infants plexus of the pylorus in hypertrophic pyloric stenosis in infant.
(Pylorospasm). Acta paediat. (Uppsala), 45, Suppl. 107.

Belding, H. H. and Kernohan, J. W. (1953). A morphologic study of the myenteric plexus and musculature of the pylorus with special reference to the changes in hypertrophic pyloric stenosis. Surg. Gynec. Obstet., 97, 322.

Bendix, R. M. and Necheles, H. (1947). Hypertrophic pyloric stenosis. A follow-up study. J. Amer. med. Ass., 135, 331.

Blair, P. (1717). An account of the dissection of a child. Communicated in a letter to Dr. Brook Taylor, R.S. Secr. Phil. Trans. $B, 30,631$.

Cameron, H. C. (1925). Some forms of vomiting in infancy. Brit. med. J., 1, 815.
Carter, C. O. and Powell, B. W. (1954). Two-generation pyloric stenosis. Lancet, 1, 746.

Cautley, E. and Dent, C. T. (1903). Congenital hypertrophic stenosis of the pylorus and its treatment by pyloroplasty. Med.chir. Trans., 86, 471 .

Dogiel, A. S. (1899). Ueber den Bau der Ganglien in den Geflechten des Darmes und der Gallenblase des Menschen und der Säugethiere. Arch. Anat. Physiol., Lpz., Anat. Abth., 61, 130.

Friesen, S. R., Boley, J. O. and Miller, D. R. (1956). The myenteric plexus of the pylorus: its early normal development and its plexus of the pylorus: its early normal development and its

changes in hypertrophic pyloric stenosis. Surgery, 39, 21.
Gross, R. E. (1953). The Surgery of Infancy and Childhood. Saunders, Philadelphia.

Herbst, C. (1934). Mikroskopische Untersuchungen der intramuralen Magennerven beim Pylorospasmus. Z Kinderheilk., $56,122$.

Nielsen, O. S. (1956). Histological changes of the pyloric myenteric plexus in infantile pyloric stenosis. Studies on surgical biopsy plexus in infia paediat. (Uppsala), 45,636.

specimens. Acta paediat. (Uppsala), 45, 636 .
Rintoul, J. R. (1959). The comparative morphology of the enteric neurons (Proc. Anat. Soc. Gt. Brit. and Ireland). J. Anat. (Lond.), 93, 583.

(1960). The comparative morphology of the enteric nerve plexuses. M.D. Thesis, University of St. Andrews.

Roberts, P. A. Lane (1959). Pathology of infantile hypertrophic pyloric stenosis. Proc. roy. Soc. Med., 52, 1022

Svenson, O. (1958). Paediatric Surgery. Appleton-Century-Crofts, New York.

Taylor, Selwyn (1959). Pyloric stenosis before and after Ramstedt. Arch. Dis. Childh., 34, 20.

Wood, E. C. and Smellie, J. M. (1951). Congenital hypertrophic pyloric stenosis. Review of 320 cases. Lancet, 2, 3. 